\title{
Land use change suppresses precipitation
}

\author{
W. Junkermann ${ }^{1}$, J. Hacker ${ }^{2}$, T. Lyons ${ }^{3}$, and U. Nair ${ }^{4}$ \\ ${ }^{1}$ Forschungszentrum Karlsruhe, IMK-IFU, Garmisch-Partenkirchen, Germany \\ ${ }^{2}$ Airborne Research Australia, Flinders University, Adelaide, Australia \\ ${ }^{3}$ Murdoch University, Perth, Australia \\ ${ }^{4}$ National Space Science Technology Center, Huntsville, Alabama, USA
}

Received: 14 April 2009 - Published in Atmos. Chem. Phys. Discuss.: 8 May 2009

Revised: 13 August 2009 - Accepted: 15 August 2009 - Published: 10 September 2009

\begin{abstract}
A feedback loop between regional scale deforestation and climate change was investigated in an experiment using novel, small size airborne platforms and instrument setups. Experiments were performed in a worldwide unique natural laboratory in Western Australia, characterized by two adjacent homogeneous observation areas with distinctly different land use characteristics. Conversion of several ten thousand square $\mathrm{km}$ of forests into agricultural land began more than a century ago. Changes in albedo, surface roughness, the soil water budget and the planetary boundary layer evolved over decades. Besides different meteorology, we found a significant up to now overlooked source of aerosol over the agriculture area. The enhanced number of cloud condensation nuclei is coupled through the hydrological groundwater cycle with deforestation. Modification of surface properties and aerosol number concentrations are key factors for the observed reduction of precipitation. The results document the importance of aerosol indirect effects on climate due to nanometer size biogenic aerosol and human impact on aerosol sources.
\end{abstract}

\section{Introduction}

Aerosols of natural and anthropogenic origin have important climate effects through interaction with clouds, which are among the main uncertainties in climate models due to the large variability of aerosol sizes, types and 3-D-distributions (Chin et al., 2009). Besides direct effects on the radiation budget (Ramanathan et al., 2007) aerosols modify the albedo of clouds and are suspected to impact precipitation probabil-

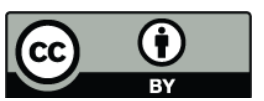

Correspondence to: W. Junkermann (wolfgang.junkermann@imk.fzk.de) ities. Experimental investigations of these indirect effects are typically restricted to high concentration emissions in industrial and urban aerosol plumes (Givati and Rosenfeld, 2004; Rosenfeld, 2006) where changes of cloud properties are visible from satellites (Rosenfeld et al., 2000, 2006) although in more remote areas slight changes in the aerosol concentrations can have a large regional scale impact. This study reports on investigations of aerosols over a remote natural laboratory, along the $\sim 1500 \mathrm{~km}$ long Vermin Proof Fence, also called "State Barrier Fence", in Western Australia. This fence, built in the first decade of the 20th century, separates an area of $>100.000$ square $\mathrm{km}$ of homogeneous terrain, converted to arable land (west), from the natural vegetation of inner Australia, conserved as a nature preserve (east). The fence protects the agriculture from an invasion of animals but also protects the nature preserve from farming pressure and serves as a clear cut between the two types of landscape. Recent satellite images indicate that the fence also works as a separation line between different meteorological regions. Clouds, for example, develop more often over regions with natural vegetation (Lyons, 2002). Early surveys of aerosols over Australia (Bigg and Turvey, 1978; Bigg et al., 1984) found generally clean conditions in remote areas with less than 1000 ultrafine $\left(>20 \mathrm{~nm}\right.$ ) particles $/ \mathrm{cm}^{3}$ throughout most of Australia. Local enhancements were occasionally observed in coastal areas, but, for the analysis of particle distributions they were considered to be unimportant (Bigg et al., 1984). However, higher numbers of ultrafine particles are now also found in several other locations with high biogenic nucleation mode aerosol precursors emissions above and downwind of tropical forests on the Australian east coast (Suni et al, 2008; Guo et al., 2008). Ultrafine particles observed in high numbers off the Queensland coastline resulted from emissions from the Great Barrier Reef although with

Published by Copernicus Publications on behalf of the European Geosciences Union. 
different chemistry compared to the Irish coastline at Mace Head (Saiz-Lopez et al., 2005, O'Dowd et al., 2007, Modini et al., 2009)

The rationale for this project was to investigate the processes behind the regional change of the precipitation patterns in Western Australia (Sadler et al., 2002). The western tip of the continent has experienced a reduction of precipitation by about $30 \%$ (from an average of $325 \mathrm{~mm} / \mathrm{a}$ ) since the 1970's, attributed to a change in the large scale surface pressure patterns of the southern ocean (Allan and Haylock, 1993; Smith et al., 2000) with a concurrent reduction in surface water fluxes (Bates et al., 2008). On top of the long-term dry climate trend a shift of precipitation from the agricultural areas to regions with natural vegetation was observed with an increase by about $20 \%$ (Sadler, 2002). This pattern is most probably due to a combination of regional processes rather than to large scale circulation changes. Modifications of albedo and surface roughness by land use affect regional meteorology and cloudiness (Pitman et al., 2004; Ray et al., 2003). A regional change of aerosol populations could be another important factor controlling the conversion of water vapour and cloud condensation nuclei to raindrops (Fletcher, 1962; Flossmann, 1998; Toon, 2000; Lohmann and Feichter, 2005). A response of clouds to additional aerosols depends on convection and temperature levels (Teller and Levin, 2006; Rosenfeld et al., 2008), but in general, precipitation would be reduced or regionally redistributed (Givati and Rosenfeld, 2004). A recent critical review of the current state of research indicated the difficulties to relate rainfall depletion to increased anthropogenic aerosol numbers (Ayers, 2005) as precipitation is an effect of both, cloud dynamics and aerosol driven cloud microphysics and it would be difficult to separate these. Despite this complexity several studies not only in Australia reveal growing evidence that actually anthropogenic air pollution leads to a regional reduction of precipitation intensity (Rosenfeld et al., 2006, 2008b; Bigg, 2008).

Natural, other than industry and urban pollution, sources of aerosols have to be considered as well as potential cloud condensation nuclei. Changes in land use, surface structure and vegetation are expected to modify aerosol source strength in all size ranges. Particles originating from dust devils or farming activities are deposited rapidly. Thus the number of coarse particles in remote areas is normally low. By contrast, ultrafine particles from biogenic emissions can be high in number concentration and have long residence times. Far below the threshold to get visible, they first have to grow into size ranges of about $50 \mathrm{~nm}$ to become active in the environment either as $\mathrm{CCN}$ or haze. These aerosols typically are found either in coastal areas or above forests. There are only few measurement sites with extensive measurements. In coastal areas either Iodine chemistry or DMS derived sulphur chemistry is described as the source for nucleation (O'Dowd et al., 2007; Modini et al., 2009), while above forests biogenic emissions are the main precursors also with sulphur compounds as key reactants (Kulmala et al., 2004; Vaattovaara et al., 2006).

Here we report on a new biogenic, though human-induced, source of ultrafine particle production observed over continental Australia, which was previously overlooked. This source is intense enough to double the number of $\mathrm{CCN}$ on a regional scale. Their identification was possible only with the deployment of novel instrumentation for particle size distributions. The unique observational area with documented changes in land use initiated 150 years ago, and the novel experimental approach now allow an analysis of the impact of land use change on regional scale climate.

\section{Experimental}

To investigate the complex regional climate in Western Australia (Fig. 1), we launched a new project that included a small, lightweight, aerosol package on an airborne platform. We used small, low and slow flying aircraft which allow investigations very close to the surface, yet still able to cover distances of more than $200 \mathrm{~km}$ and climbing rapidly above cloud levels. The region is part of the Yilgarn Craton, a flat terrain of more than $1000 \times 1000 \mathrm{~km}$ between 265 and $365 \mathrm{~m}$ above sea level (Benison, 2007). The agricultural land along the fence extends over $\sim 300 \mathrm{~km} \mathrm{~W} / \mathrm{E}$ and $>600 \mathrm{~km} \mathrm{~N} / \mathrm{S}$ direction. The remaining part of the craton is natural vegetation. Two aircraft were operated from an airstrip situated about $30 \mathrm{~km}$ from the Vermin Proof Fence in the agricultural area near Lake King township. Figure $1 b, 1 c$, and $1 d$ also shows the numerous salt lakes in the region, summer and winter vegetation and the abrupt change in vegetation at the fence. Typical flight patterns went back and forth over the two regimes at $\sim 150 \mathrm{~m}$ above ground and extended up to $150 \mathrm{~km}$ into each area. At the turning points, vertical spirals were flown up to $4000 \mathrm{~m}$ altitude, well above the planetary boundary layer. Flights were performed ten days each in summer and winter to account for seasonality in vegetation cover. Only on one day did a layer of low cumulus clouds cover both areas enabling the measurement of aerosols below cloud and corresponding cloud microphysics. Such meteorological conditions are not frequent in this semiarid area.

The aircraft, a DIMONA HK36TT-ECO, carries up to $110 \mathrm{~kg}$ scientific payload in two underwing pods which includes meteorological instrumentation (turbulence, spectral radiation and albedo) and a suite of aerosol instrumentation (Junkermann, 2005). Size distributions from 5 to $350 \mathrm{~nm}$ were measured with a scanning mobility particle sizer (Grimm SMPS+C, 2 min time resolution) and from $300 \mathrm{~nm}$ to $20 \mu \mathrm{m}$ using an optical particle counter, (Grimm $1.108,6 \mathrm{~s}$ resolution). For rapid detection of ultrafine particles $>10 \mathrm{~nm}$ a condensation nucleus counter (TSI 3010, $1 \mathrm{~s}$ resolution) was used and cloud droplet size distributions were measured with a Forward Scattering Spectrometer Probe (FSSP-100). A second aircraft of the same type 


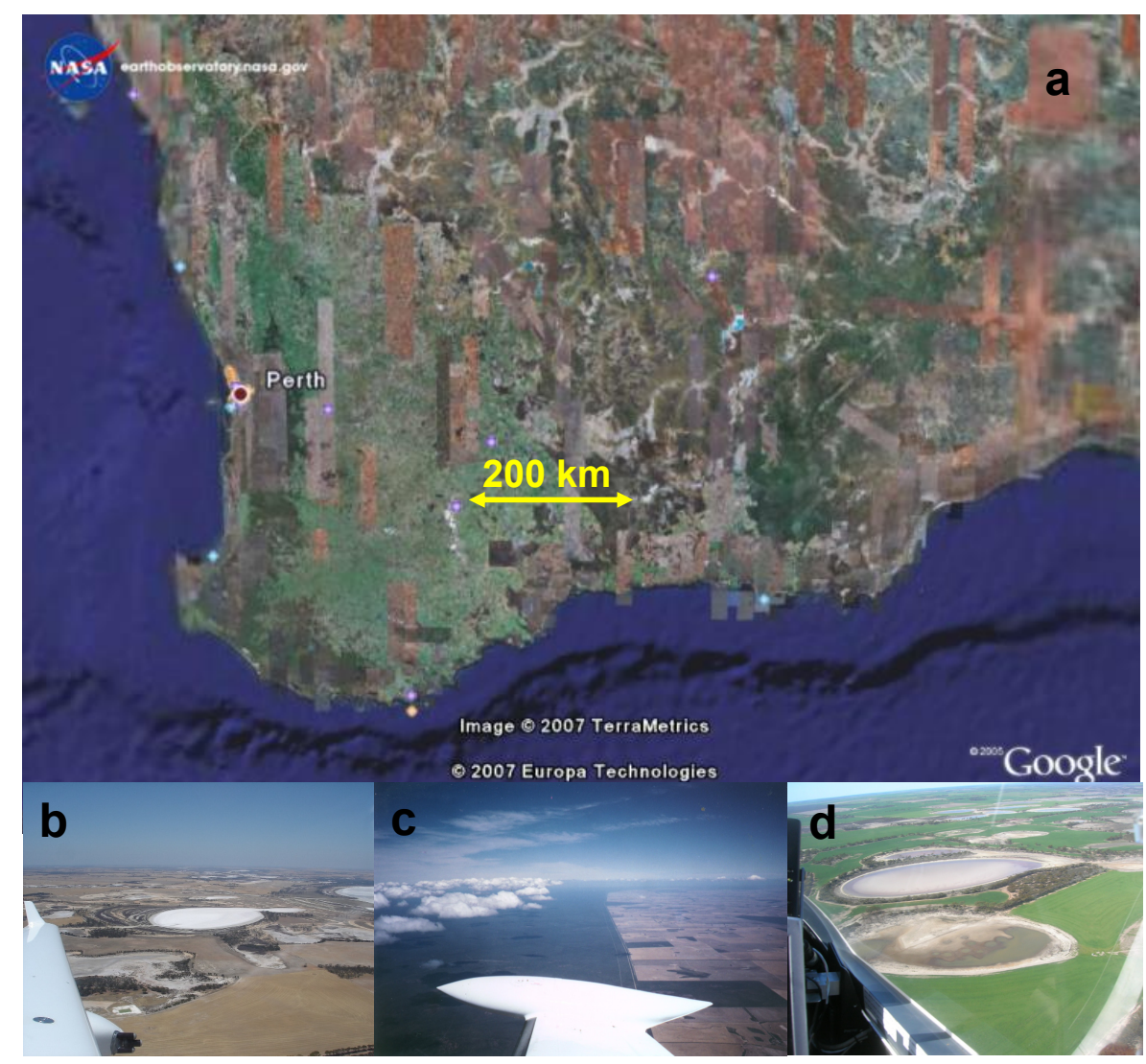

Fig. 1. Western Australia seen from the satellite (a), summer (b) and winter (d) surface conditions in the agricultural region and the State Barrier Fence area (c), in yellow the location of the flight experiments. The circular ponds (b, d) are salt lakes, bright white in summer, different colours in winter.

was equipped with turbulence, flux and remote sensing instrumentation.

\section{Results and discussion}

Our "experiment" actually began with, and benefitted from the activities of the early settlers. It took into account earlier findings and observations that date back to the end of the 19th Century when clearing of the natural forests began. During the course of the large-scale and long-term experiment the environmental impacts were already observed in the hydrological cycle after several decades. The groundwater table in the agricultural region rose from $>20 \mathrm{~m}$ to $\sim 2 \mathrm{~m}$ within 30 years since 1950 with a concurrent increase in groundwater salinity. These effects were attributed to deforestation and have been shown to be reversible by reforestation (Ruprecht and Schofield, 1991; Schofield and Bari, 1993). We found now a regional feedback to aerosol production.

Compared to the aerosol distributions known from moderate climates in the Northern Hemisphere, the ultrafine particles in Western Australia behaved totally differently. In our study, nucleation mode particles were never observed over the natural vegetation, although the eucalyptus trees are considered to emit aerosol precursor compounds like isoprene (Suni et al., 2008). Instead, all ultrafines below $10 \mathrm{~nm}$ were found exclusively over the agricultural land. Figure 2 shows the horizontal and vertical distribution of particles larger than $10 \mathrm{~nm}$ along a $\sim 100 \mathrm{~km}$ transect starting over natural vegetation in the East and crossing into harvested fields with a few scattered spots of natural vegetation in the West. Six such traverses for low wind conditions are displayed. Over the arable land, the ultrafine aerosol concentration was always more than an order of magnitude higher as compared to the forested area. Up to $30000 / \mathrm{cm}^{3}$ were found. This holds true for all flights, irrespective of the season and vegetation cover. Whenever we flew east of the fence, the numbers of ultrafine particles were low and close to continental background concentrations, and particles below $15 \mathrm{~nm}$ were almost completely absent. Fine particle numbers $(>300 \mathrm{~nm}$ ) were very low everywhere, i.e. below $10 / \mathrm{cm}^{3}$, approximately $1 / 10$ of mid European remote levels. The apparent lack of nucleation mode particles over the natural vegetation might have two reasons, the very low concentration of sulphur dioxide required for nucleation from biogenic precursors or the dry 


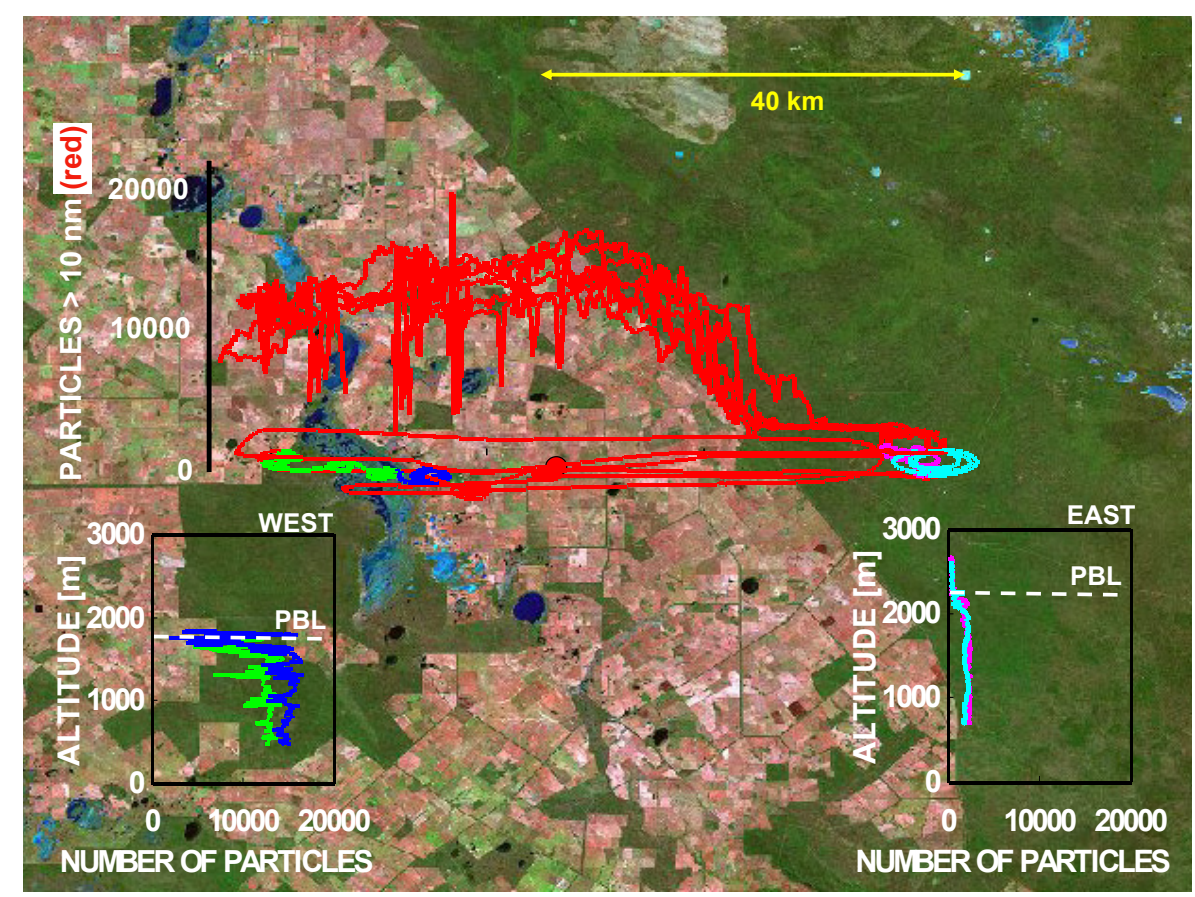

Fig. 2. Flight patterns crossing the State Barrier Fence, 9 December 2007, summer season, Number of ultrafine particles ( $>10 \mathrm{~nm}$, red) on six horizontal flight legs, and vertical profiles east and west of the fence (green blue and pink). Colours mark different position for horizontal and vertical flight legs. In the convective boundary layer the aerosols are well mixed with altitude (lower inserts WEST and EAST).

environmental conditions compared to east Australia which affect the biogenic emission cycles. The density of trees in the area is comparable to the boreal forests in Finland, which act as strong precursor emitters.

Highest particle numbers and especially the very small sizes below $10 \mathrm{~nm}$, were found over the smaller salt lakes in the agricultural region. These lakes are lined up like chains along ancient river beds. Very high numbers in the smallest particle size bins are indicative of gas to particle conversion (nucleation) from surface emissions. Size distributions are also dependent on the time of the day. Figure 3 shows the aerosol size distributions over a medium size salt lake (Lake Stubbs) in the morning and the early afternoon and for comparison over the natural forest on the right side. These size distributions agree well with nucleation patterns observed at other regions of the world, both in magnitude and temporal evolution (Kulmala et al., 2004; Laaksonen, et al., 2005). The shape of the size distributions allows tracing back the time since nucleation occurred. Already in a short distance from the lakes fresh particles were strongly reduced, evidence for the exclusive production from the salt lakes, in contrast to production from soil or agricultural vegetation. The chemical composition of these freshly nucleated particles is not yet known as no instruments for the measurement of chemical composition were on-board the aircraft. However, the aerosol chemistry in the groundwater coupled lakes might be similar to aerosols present in coastal environments with a large contribution of organo-halogen, possibly iodine, compounds (Saiz-Lopez et al., 2006). The nucleation could not be traced back to emissions from vegetation as was the case in other investigations (Kulmala et al., 2004). As shown in Fig. 3, these ultrafine particles grow rapidly in size at a rate of $\sim 6 \mathrm{~nm} / \mathrm{h}$ and can reach CCN sizes within a few hours. Clearly, these particles are generated locally. Any impact of a city plume from Perth, more than $400 \mathrm{~km}$ away (Bigg and Turvey, 1984) can be excluded, based on the characteristics of the measured size distributions.

The total number of particles greater than $50 \mathrm{~nm}$ over both areas, as shown in the Figs. 4 and 5, was calculated from the individual size distribution measurements. $50 \mathrm{~nm}$ is the approximate threshold for activation of cloud condensation nuclei depending on supersaturation and, to a lesser extend, the chemical composition (Dusek et al., 2006). The total number of these potential cloud condensation nuclei in the west (i.e. over agricultural land) was typically more than twice as high as in the east.

Amongst the other parameters observed from the aircraft, the most striking differences over both areas were recorded in the meteorological variables, temperature, latent and sensible heat fluxes, albedo and water vapour as in previous campaigns. Major seasonal differences were observed in the water vapour budget. In winter, the growing wheat evaporates far more water (Lyons et al., 1993, 1996) than the natural vegetation which is reflected in higher water vapour content aloft (Fig. 4). 

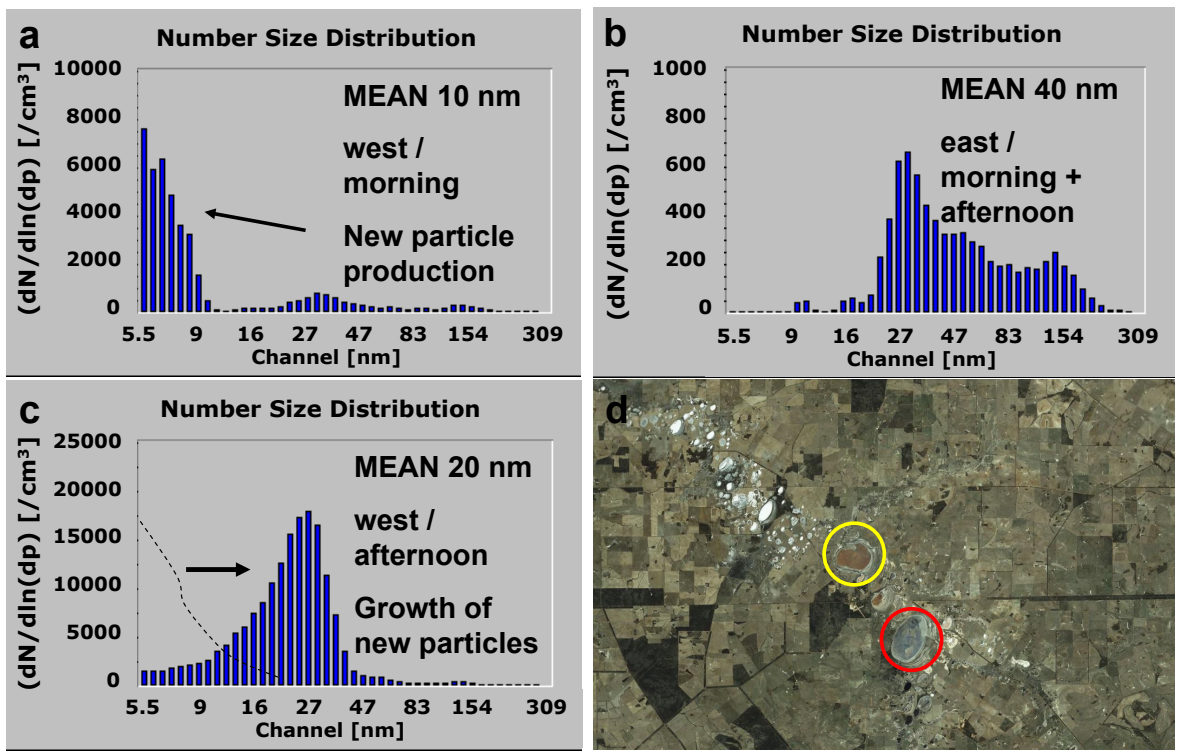

Fig. 3. Diurnal change of size distributions under calm conditions (wind speed below $2.5 \mathrm{~m} / \mathrm{s}$ ). Nucleation mode particles were found only over the northern Lake (Lake Stubbs, yellow), not over the southern one (Lake Buchan, red). Note also the surface colours indicating different humidity. The white spots are smaller salt lakes (d). Size distributions of the ultrafine particles over Lake Stubbs in the west during the main nucleation phase ( 11:00 a.m. local), (a) and three hours later after aging of the particles (c). Size distribution in the east (b) without change between morning and afternoon. Note the different scales in the total numbers. The main fraction of the fresh nucleation mode particles at 02:00 p.m. local time were still smaller than cloud condensation nuclei sizes $(50 \mathrm{~nm})$ but the CCN range was already affected.
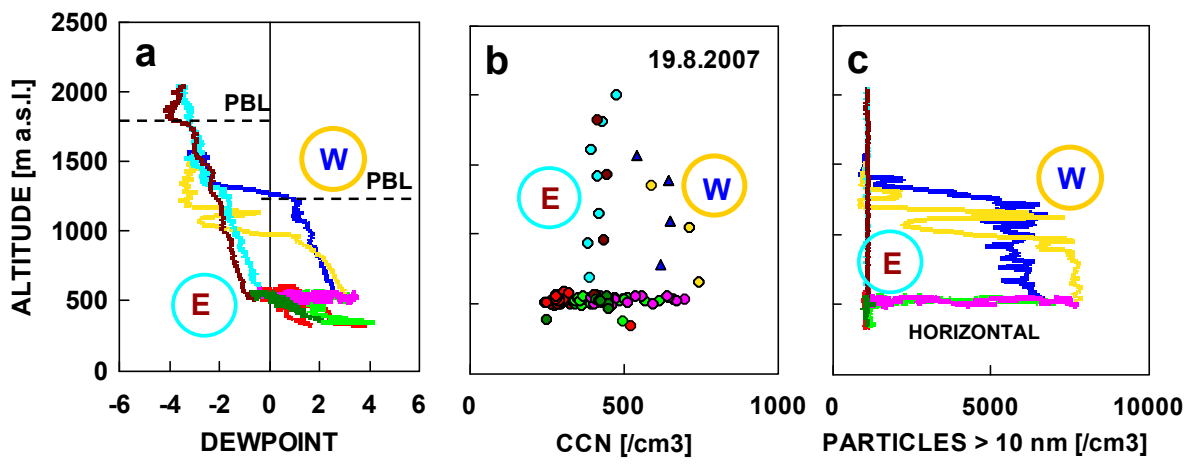

Fig. 4. Dewpoint (water vapour, used to define PBL) (a), (b) calculated CCN (see text), (c) vertical distributions above the agriculture (W, yellow and blue), and above the natural vegetation ( $\mathrm{E}$, light blue and brown) under clear sky conditions. In winter the water vapour over the agriculture is enhanced by increased emissions from the wheat.

In both seasons the higher surface temperature of the "dark" natural vegetation results in an increased depth of the convective layer, an additional $500 \mathrm{~m}$ over a distance of 50 $100 \mathrm{~km}$ (see PBL levels Figs. 2 and 4). This evolution of the PBL is also confirmed by concurrent rawin sonde ascents in the forest and the agriculture. This could imply a thermally driven exchange of air masses between the two areas, similar to a sea breeze circulation. However, the exclusive appearance of ultrafine particles above the wheat fields (Fig. 2) is an indicator that no significant air mass exchange through local circulation systems existed across the fence.
On one day (21 August 2007), a single layer of shallow cumulus clouds between 4 and 5 octa covered both areas allowing a comparison of below-cloud aerosol and in-cloud droplet size distributions. Vertical profiles and about 20-30 minutes of cloud scans were flown first over the agricultural region, and about two hours later over the natural region. Over the wheat fields both, higher water vapour and a lower surface temperature resulted in a lower cloud base comparable to earlier results regarding the planetary boundary layer thickness (Lyons et al., 1993, 1996). Within the three hours from 11:00 to 14:00 local time, between the first ascending profile and the last descending profile, a slow further growth 

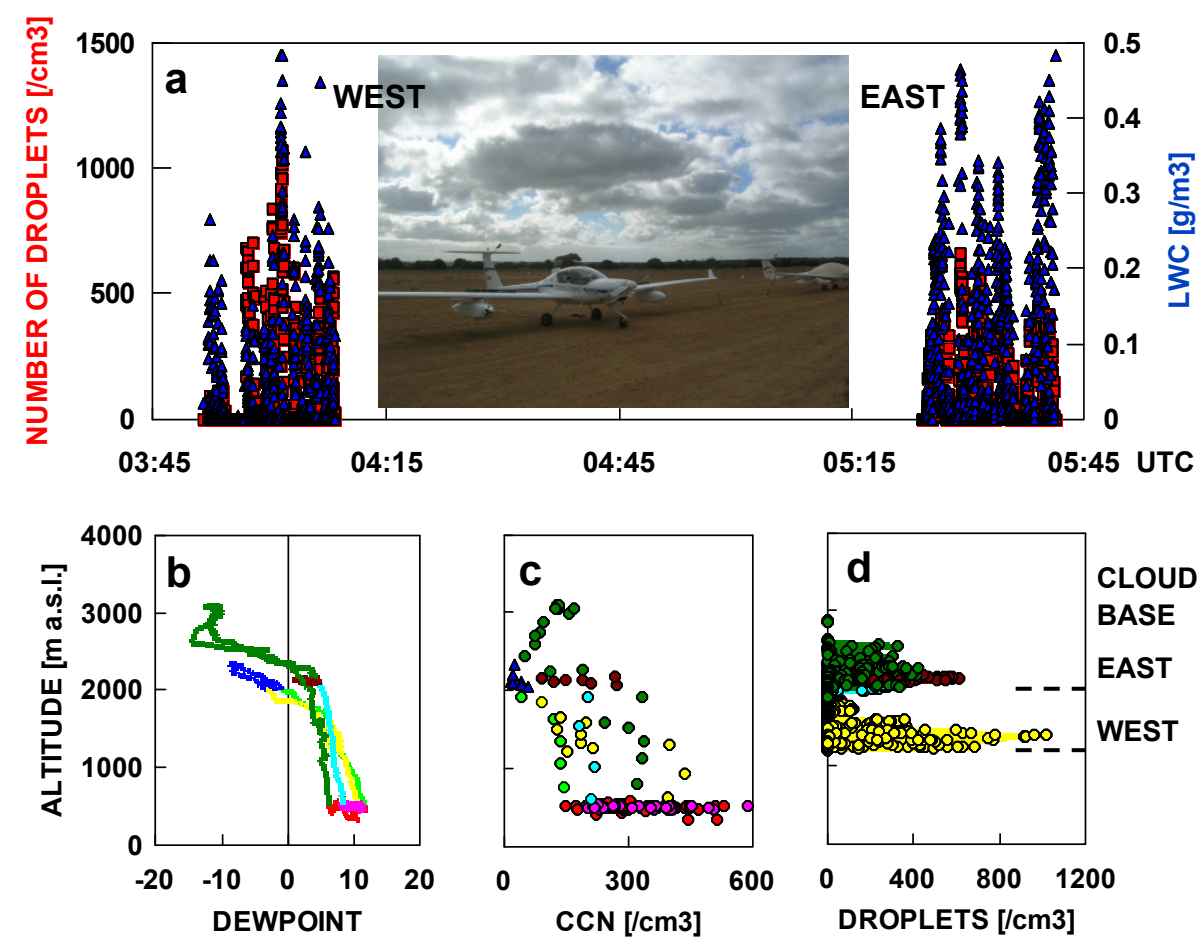

Fig. 5. Cloud day (21 August 2007, winter). Upper panel: red squares: number of droplets $/ \mathrm{cm}^{3}$, blue triangles: liquid water content. The left group of data was measured in the west (agriculture), the right in the east (natural vegetation). Lower panel: dewpoint, cloud condensation nuclei and cloud droplets are shown in the bottom panels (b,c,d) from ascents/descents on both sides of the Fence. The difference between the green (11:00 LT) and yellow profiles (12:00 LT) shows the rapid growth of nucleation mode particles into the CCN range. The different condensation levels are a result of the lower temperatures and higher water vapour content in the west. The light blue (13:15 LT), brown and dark green (14:00 LT) data are from the natural vegetation side. Times are given in local time (LT) \pm 10 min for each profile. Note the differences in dewpoint and cloud base.

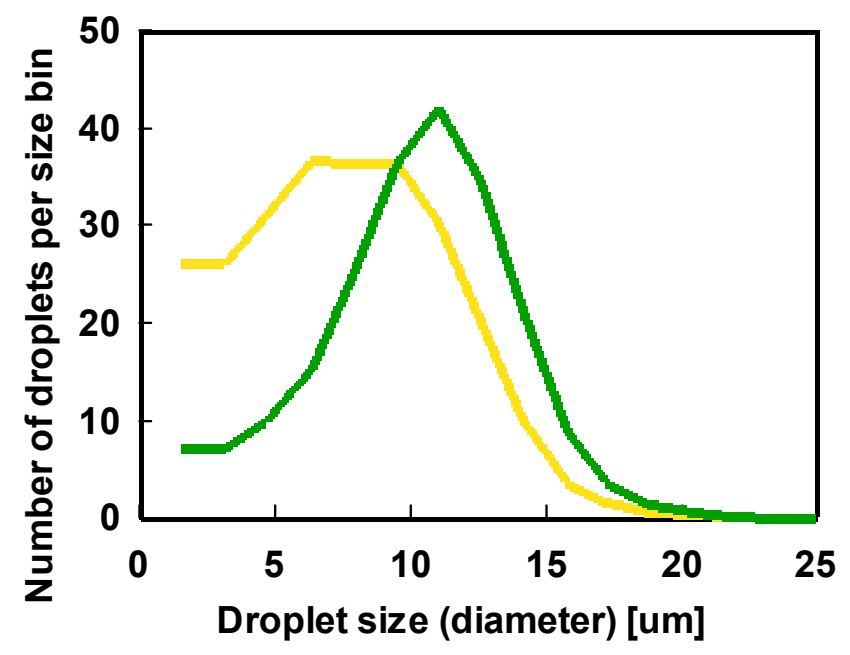

Fig. 6. Droplet size distributions over agriculture (yellow) and natural vegetation (green). Both droplet spectra do not reach the threshold for precipitation formation. of the planetary boundary layer thickness can be expected, explaining part of the very high difference between west and east, although in the one hour intervals between the two profiles on each side no significant corresponding growth rate was observed. The vertical extend of the clouds was similar over both areas, approximately $600 \mathrm{~m}$. Figure 5 shows cloud microphysical data, dewpoint, $\mathrm{CCN}$ and cloud droplet number as a function of altitude. In both cases, the aircraft climbed above the cloud tops to measure the radiation fluxes.

The corresponding cloud droplet measurements over both areas are shown in the upper part of Fig. 5. Higher cloud droplet numbers were observed over the agriculture and higher liquid water content over the natural vegetation, although water vapour below the cloud was higher over the agricultural fields. This is a result of lower convective energy over the agriculture. Simple model calculations with a cloud model by Johnson (1982) predict lower droplet numbers for reduced updraft below cloud base as due to lower supersaturation in the cloud, a smaller fraction of the below cloud aerosol will be activated. To match the observations, would require a doubling of the $\mathrm{CCN}$ as observed. The cloud fields over both areas did not produce precipitation. The probability of rain generation within a cloud depends on 
Table 1. Meteorological and cloud physics parameters below (ground and cloud base) and within cloud.

\begin{tabular}{|c|c|c|c|c|}
\hline \multirow[t]{2}{*}{ Parameter } & \multicolumn{2}{|c|}{ West (agriculture) } & \multicolumn{2}{|c|}{ East (natural vegetation) } \\
\hline & ground & cloud base & ground & cloud base \\
\hline Temperature $\left[{ }^{\circ} \mathrm{C}\right]$ & 16 & 10 & 20 & 6 \\
\hline Pressure $[\mathrm{hPa}]$ & 975 & 900 & 975 & 800 \\
\hline Dewpoint $\left[{ }^{\circ} \mathrm{C}\right]$ & 11 & 9 & 6 & 3.5 \\
\hline Water $[\mathrm{g} / \mathrm{m} 3]$ & 9.9 & 8.8 & 6.9 & 6.1 \\
\hline Cloud droplets [/cm3] & \multicolumn{2}{|c|}{247} & \multicolumn{2}{|c|}{198} \\
\hline Average diameter [um] & \multicolumn{2}{|c|}{8.3} & \multicolumn{2}{|c|}{9.5} \\
\hline Liquid water content $[\mathrm{g} / \mathrm{m} 3]$ & \multicolumn{2}{|c|}{0.10} & \multicolumn{2}{|c|}{0.15} \\
\hline
\end{tabular}

the availability of droplets above a threshold size $(\sim 28 \mu \mathrm{m})$ in order to induce growth to raindrops (Rosenfeld and Gutmann, 1994). The droplets in the clouds over both areas did reach this threshold only occasionally, but the droplet size distributions indicate that the clouds over the forest were by far closer to precipitation (Fig. 6). The higher water vapour content over the agricultural region (west of the Fence) was not reflected in the differences of liquid water content in the cloud as a result of lower convective energy (Table 1).

Although it is difficult to collect statistically relevant data on cloud microphysics and aerosols from only one day of aircraft data, the results of aerosol and cloud microphysical agree well with model results of increased particle numbers and their interaction with warm cloud microphysical processes. The additional CCN increase the number of cloud droplets competing for condensable water. The precursor aerosol from salt lake emissions is thus expected to increase cloud lifetime and to decrease precipitation probability from "warm" cumulus clouds. A significant other source for $\mathrm{CCN}$ would not be in agreement with the measured size distributions.

The lack of airmass exchange across the fence, marked by the step function increase in the aerosol number concentration, indicates that the water cycle over both areas is regionally decoupled. A reduction of precipitation is therefore a regional phenomena, linked to small scale meteorology and aerosol availability.

The mechanism for the new particle production over the salt lakes can not be elucidated from airborne measurements. However, different colours of the algae species (Figs. 1 and 3 ) in the lakes located in the agricultural region indicate that a variety of biochemically driven processes are at work. These are dependent on the intermittent or continuous coupling or decoupling of the lakes with the groundwater. The rise of the groundwater table was already shown to be initiated by the regional scale deforestation (Ruprecht and Schofield, 1991) which occurred over the last century. Since particle production is dependent on lake chemical and biochemical processes, and subsequent release of gases to the atmosphere, it follows that it also can be related to deforestation.

\section{Summary}

Airborne measurements using a novel platform and instrumentation package were performed over two remote regions with equal orography but significantly different land use characteristics. Large scale modifications of the vegetation cover caused changes in local convection and water vapour availability. To explain the changes in precipitation patterns besides the reduction of convection additional cloud condensation nuclei $(\mathrm{CCN})$ are required. Elevated $\mathrm{CCN}$ numbers were found exclusively over the agricultural area traceable to local sources linked to salt lakes geochemistry.

Taking into account the observations over more than a century, the following sequence can be established:

Deforestation began in the mid 19th century and was terminated after 100 years, at about the same time when the precipitation rapidly decreased by $30 \%$ within a decade. Rising groundwater tables and increased groundwater salinity was concurrently observed since 1970 . Eventually the groundwater table reaches the lake level, modifies the lake biogeochemistry and triggers production of aerosol precursors. These nm size particles grow to $\mathrm{CCN}$ sizes and double the $\mathrm{CCN}$ number concentration over the agricultural area where suppression of precipitation has been observed. In parallel, the increased albedo of the agricultural area reduces the convective energy. Thus cloud development is suppressed. The higher water vapour above the wheat fields results in a lower cloud base and higher (warmer) cloud top temperatures.

Although salt lakes are located on both sides of the fence separating the two contrasting regions, the lakes in the natural vegetation region do not emit any aerosol precursor material. Hydrologic reasons such as the variable groundwater table would be a plausible explanation for the different biogeochemical characteristics of the lakes (Benison, 2007).

The chemical composition of the salt lake emissions is unknown but is expected to include organo-halogen compounds. Since halogen emissions from salt lakes and salt marshes might have a regional to global effect on air chemistry also, the detailed investigation of the chemical and hydrological processes in the salt lakes will be the subject of upcoming research. 
The results of the Western Australian experiment show the importance of local production of ultrafine aerosols over remote areas that subsequently grow into $\mathrm{CCN}$ and can cause regional scale changes in precipitation. Any changes of the $\mathrm{CCN}$-aerosol source strength, either anthropogenic or induced by climate change related biosphere response, will have a feedback on the water budget and should be taken into account in order to reduce uncertainties in the models. Both, increase or suppression of precipitation after change of land use, are possible. The processes in cloud microphysics are the same as from industrial and urban pollution aerosol, only the size, intensity and distribution of sources are different. It is important to note that these ultrafine particles cannot be detected by remote sensing techniques but require the deployment of instruments as presented in this paper.

Acknowledgements. This research was supported by US National Science Foundation grant ATM-0523583 and the Australian Research Council's Discovery funding scheme (project DP0664515). One of the aircraft was donated by the late Ms. Joyce Schultz. All of this assistance is gratefully acknowledged.

Edited by: T. Kirchstetter

\section{References}

Allan, R. J. and Haylock, M. R.: Circulation features associated with the winter rainfall decrease in Southwestern Australia, J. Climate, 6, 1356-1367, 1993.

Ayers, G.: Air Pollution and Climate Change: Has air pollution suppressed rainfall over Australia, Clean Air and Environmental Quality, 39(2), 51-57, 2005.

Bates, B. C., Kundzewicz, Z. W., Wu, S., and Palutikof, J. P. (Eds.): Climate Change and Water. Technical Paper of the Intergovernmental Panel on Climate Change, IPCC Secretariat, Geneva, 210 pp., 2008.

Benison, K. C.: Sedimentology of Acid Saline Lakes in Southern Western Australia: Newly Described Processes and Products of an Extreme Environment, J. Sediment. Res., 77, 366-388; doi:10.2110/jsr.2007.038, 2007.

Bigg, E. K. and Turvey, D. E.: Sources of atmospheric particles over Australia, Atmos. Environ., 12, 1643-1655, 1978.

Bigg, E. K., Gras, J. L., and Evans, C.: Origin of Aitken particles in remote regions of the Southern Hemisphere, J. Atmos. Chem., 1, 203-214, 1984.

Bigg, E. K.: Trends in rainfall associated with sources of air pollution, Environ. Chem., 5, 184-193, 2008.

Chin, M., Kahn, R. A., and Schwartz, S. E. (Eds.): Atmospheric Aerosol Properties and Impacts on Climate, a report by the U.S. Climate Change Science Program and the Subcommittee on Global Change Research. NASA, Washington, D.C., USA, 2009.

Dusek, U., Frank, G. P., Hildebrandt, L., Curtius, J., Schneider, J., Walter, S., Chand, D., Drewnick, F., Hings, S., Jung, D., Borrmann, S., and Andreae, M. O.:, Size matters more than chemistry for cloud-nucleating ability of aerosol particles, Science, 312, 1375-1378, 2006.

Guo, H., Ding, A., Morawska, L., He, C., Ayoko, G., Li, Y.-S., and Hung, W.-T.: Size distribution and new particle formation in subtropical eastern Australia, Environ. Chem., 5, 382-390, 2008.
Fletcher, N.: The Physics of Rainclouds, Cambridge Univ. Press, Cambridge, 1962.

Flossmann, A.: Clouds and pollution, Pure Appl. Chem., 70(7), 1345-1352, 1998.

Givati, A. and Rosenfeld, D.: Quantifying Precipitation Suppression Due to Air Pollution, J. Appl. Meteorol., 43, 1038-1056, 2004.

Johnson, D. B.: The Role of Giant and Ultragiant Aerosol Particles in Warm Rain Initiation, J. Atmos. Sci., 39, 448-460, 1982.

Junkermann, W.: The actinic UV-radiation budget during the ESCOMPTE campaign 2001: Results of airborne measurements with the microlight research aircraft D-MIFU, Atmos. Res., 74, 461-475, 2005.

Kulmala, M., Vehkamäki, H., Petäjä, T., Dal Maso, M., Lauri, A., Kerminen, V. M., Birmili, W., and McMurry, P. H.: Formation and growth rates of ultrafine atmospheric particles: a review of observations, J. Aerosol Sci., 35, 143-176, 2004.

Laaksonen, A., Hamed, A., Joutsensaari, J., Hiltunen, L., Cavalli, F., Junkermann, W., Asmi, A., Fuzzi S., and Facchini, M. C.: Cloud Condensation Nucleus Production from Nucleation Events at a Highly Polluted Region, Geophys. Res. Lett., 32, L06812, doi:10.1029/2004GL022092, 2005.

Lohmann, U. and Feichter, J.: Global indirect aerosol effects: A review. J., Atmos. Chem. Phys., 5, 715-737, 2005, http://www.atmos-chem-phys.net/5/715/2005/.

Lyons, T. J., Schwerdtfeger, P., Hacker, J. M., Forster, I. J., Smith, R. G. C., and Huang, X.: Land atmosphere interaction in a semiarid region - the bunny fence experiment, B. Am. Meteorol. Soc., 74, 1327-1334, 1993.

Lyons, T. J., Smith, R. C. G., and Huang, X.: The impact of clearing for agriculture on the surface energy budget, Int. J. Climatol., 16, 551-558, 1996.

Lyons, T. J.: Clouds prefer native vegetation, Meteorol. Atmos. Phys., 80, 131-140, 2002.

Modini, R. L., Ristovski, Z. D., Johnson, G. R., He, C., Surawski, N., Morawska, L., Suni, T., and Kulmala, K.: New particle formation and growth at a remote, sub-tropical coastal location, Atmos. Chem. Phys. Discuss., 9, 12 101-12 139, 2009, http://www.atmos-chem-phys-discuss.net/9/12101/2009/.

O’Dowd, C. D., Yoon, Y. J., Junkermann, W., Aalto, P., Kulmala, M., Lihavainen, M., and Viisanen, M. Y.: Airborne measurements of nucleation mode particles I: coastal nucleation and growth rates, Atmos. Chem. Phys., 7, 1491-1501, 2007, http://www.atmos-chem-phys.net/7/1491/2007/.

Pitman, A. J., Narisma, G. T., Pielke Sr., R. A., and Holbrook, N. J.: Impact of land cover change on the climate of southwest Western Australia, J. Geophys. Res., 109, D18109, doi:10.1029/2003JD004347, 2004.

Ramanathan, V., Muvva, V., Ramana, G., Roberts, G., Kim, D., Corrigan, C., Chung, C., and Winker, D.: Warming trends in Asia amplified by brown cloud solar absorption, Nature, 448, 575-578, 2007.

Ray, D. K., Nair, U. S., Welch, R. M., Han, Q., Zeng, J., Su, W., Kikuchi, T., and Lyons, T. J.: Effects of land use in Southwest Australia: 1. Observations of cumulus cloudiness and energy fluxes, J. Geophys. Res., 108, 4414, doi:10.1029/2002JD002654, 2003. 
Rosenfeld, D. and Gutmann, G.: Retrieving microphysical properties near the tops of potential rain clouds by multispectral analysis of AVHRR data, Atmos. Res., 34, 259-283, 1994.

Rosenfeld, D., Lensky, I.M., Peterson, J., and Gingis, A.: Potential impacts of air pollution on precipitation in Australia, Clean Air and Environmental Quality, 40, 43-49, 2006.

Rosenfeld, D., Lohmann, U., Rage, G. B., O’Dowd, C. D., Kulmala, M., Fuzzi, S., Reissell, A., and Andreae, M. O.: Flood or Draught: How do Aerosols Affect Precipitation?, Science, 321, 1309, doi:10.1126/science.1160606, 2008a.

Rosenfeld, D., Woodley, W. L., Axisa, D., Freud, E., Hudson, J. G., and Givati, A.: Aircraft measurements of the impacts of pollution aerosols on clouds and precipitation over the Sierra Nevada, J. Geophys. Res., 113, D15203, doi:10.1029/2007JD009544, 2008b.

Ruprecht, J. K., and Schofield, N. J.: Effects of partial deforestation on hydrology and salinity in high salt storage landscapes. II. Strip, soils and parkland clearing, J. Hydrol., 129, 39-55, 1991.

Sadler, B.: Climate variability and change in south west Western Australia, Indian Ocean Climate Initiative Panel, c/-Department of Environment, Water and Catchment Protection, WA, http://www.waterandclimateinformationcentre.org/ resources/8012007_IOCI2002.pdf, 2002.

Saiz-Lopez, A., Plane, J. M. C., McFiggans, G., Williams, P. I., Ball, S. M., Bitter, M., Jones, R. L., Hongwei, C., and Hoffmann, T.: Modelling molecular iodine emissions in a coastal marine environment: the link to new particle formation, Atmos. Chem. Phys., 6, 883-895, 2006,

http://www.atmos-chem-phys.net/6/883/2006/.
Suni, T., Kulmala, M., Hirsikko, A., Bergman, T., Laakso, L., Aalto, P. P., Leuning, R., Cleugh, H., Zegelin, S., Hughes, D., van Gorsel, E., Kitchen, M., Vana, M., Hõrrak, U., Mirme, S., Mirme, A., Sevanto, S., Twining, J., and Tadros, C.: Formation and characteristics of ions and charged aerosol particles in a native Australian Eucalypt forest, Atmos. Chem. Phys., 8, 129-139, 2008, http://www.atmos-chem-phys.net/8/129/2008/.

Schofield, N. J. and Bari, M. A.: Valley reforestation to lower saline groundwater tables - Results from Stene Farm, WesternAustralia, Aust. J. Soil Res., 29, 635-650, 1993.

Smith, I. N., McIntosh, P., Ansell, T. J., Reason, C. J. C., and McInnes, K.: Southwest Western Australian winter rainfall and its association with Indian Ocean climate variability, Int. J. Climatol., 20, 1913-1930, 2000.

Teller, A. and Levin, Z.: The effects of aerosols on precipitation and dimensions of subtropical clouds: a sensitivity study using a numerical cloud model, Atmos. Chem. Phys., 6, 67-80, 2006

Toon, O. B.: How pollution suppresses rain, Science, 287, 17631765, 2000.

Tunved, P., Hansson, H. C., Kerminen, V. M., Ström, J., Dal Maso, M., Lihavainen, H., Viisanen, Y., Aalto, P., Komppula, M., and Kulmala, M.: High natural aerosol loading over boreal forests, Science, 312, 261-263, 2006.

Vaattovaara, P., Huttunen, P. E., Yoon, Y. J., Joutsensaari, J., Lehtinen, K. E. J., O’Dowd, C. D., and Laaksonen, A.: The composition of nucleation and Aitken mode particles during coastal nucleation events: evidence for marine secondary organic contribution, Atmos. Chem. Phys., 6, 4601-4616, 2006, http://www.atmos-chem-phys.net/6/4601/2006/. 